\title{
Building Defense Institutions: The Broader Context Today
}

Peter Faber *

When the Soviet empire imploded, hopes of a post-Westphalian peace first rose, and then fell. The end of history did not come, nor did uncomfortable discontinuities coalesce into new international patterns. In the wake of the 2001 terrorist attacks against the United States, those who hoped for the emergence of new structures of global relations claimed that the interregnum was now over. A clearly definable historical epoch - the Age of Terror-had now emerged. To many observers, however, the years since the 9/11 attacks represent continuity rather than departure. The dissociations and confusions of the interregnum have not disappeared, and one can see terrorism as a feature of this flux rather than its end point. Drifting, in other words, continued to compete with planning; discernible order continued to battle with entropy. If the high priests of pattern identified terrorism as their preferred organizing device in the U.S., advocates of European integration touted their own organizing principle: a trans-European narrative that enjoyed growing acquiescence (if not total uncritical acceptance) throughout the 1990 s and early 2000 s.

We all know this comforting, identity-providing, and entropy-reversing narrative well. It is, in the soaring words of Jean Monnet, "a step towards the organized world of tomorrow." The European Project, in short, seeks to create "irresistible harmony" and, in due time, "a world domestic politics" (i.e., a weltinnenpolitik). ${ }^{2}$ It is also a peace project, a post-modern political norm unto itself, and a welcome insurance policy against the dubious "antics" of national-level political elites. ${ }^{3}$ Even more specifically, the European Union (EU) - as well as NATO, to a more modest degree-function as educational institutions, sources of standardization, and "huge, corrective monitoring [bodies]" for a number of nation-states. ${ }^{4}$

The above "official narrative" has served Europe remarkably well, but regional influences have begun to spill across their borders. Economic, political, social and cultural patterns of influence have become truly multiple and omni-directional rather than unilateral and Western European; they are forward-looking, perhaps even postmodern,

Peter Faber is an Adjunct Professor at the Elliott School of International Relations at George Washington University in Washington, D.C. The views expressed in this article are solely his own.

1 Charles King, “A Certain Way of Being European," review of Geert Mak, In Europe: Travels Through the Twentieth Century, in the Times Literary Supplement Online (25 July 2007); available at http://tls.timesonline.co.uk/article/0,,25340-2647843,00.html.

2 Herrman E. Ott and Wolfgang Sachs, "A New Foreign Policy Agenda," Internationale Politik-Global Edition 8:1 (Spring 2007): 16-22; available at www.ip-global.org/archiv/ 2007/spring2007/a-new-foreign-policy-agenda.html.

3 Adam Krzeminski, "From Closed Circuits to Communicating Tubes," signandsight.com (18 June 2007); available at www.signandsight.com/features/1400.html.

4 Ibid. 
but also traditional. And they are expansionist, at least economically and politically, while also remaining stubbornly local in spirit.

It is within this heterogeneous mix - an inter-civilizational stew that is nothing if not eclectic - that Partner countries are working hard to meet the many challenges of Defense Institution Building (DIB). The articles that follow this one focus on the various details of this process. But by concentrating on the details, we may forget about the broader socio-political narratives that contextualize them. We may uncritically accept these narratives as unchanging and therefore inviolable; as universally applicable rather than necessarily local; and as frameworks to be complied with, rather than actively and continuously shaped. The purpose of this article is not to denigrate the remarkable post-Cold War achievements of forward-looking institutions like NATO and the EU. Instead, I hope to remind readers that the narratives they have developed and continue to promote - multi-pillar Europeanism on the part of the EU, and out-of-area expeditionary operations on the part of NATO - are not as comprehensive, either as explanations or frameworks, as they once were or need to be. The post-1989 interregnum has come and remained. It has arguably passed through two stages and has now entered a third. But what broad contextual challenges does this third stage, even with its uncertain contours, pose for those working on DIB-like projects? These challenges must be recognized for what they are, as should the uncomfortable truths that complicate the EU's official (and longstanding) roadmap for European self-emancipation and growth. After focusing on the first two topics, this article will close by mulling over which type of discourse is best suited to ensure that Defense Institution Building thrives in today's Europe.

\section{The First Requirement: To Account for Some of the Broad Contextual Challenges in Today's DIB-Development Environment}

\section{History and Memory}

Since the fall of the Berlin Wall, politicians, pundits, populists, nativists, and gardenvariety demagogues have redoubled their efforts to instrumentalize not only Europe's history, but also the memories of whole peoples. What these instrumentalists specifically want, according to Adam Phillips, is manufactured memory-i.e., a form of history that is 1) calculated and forced rather than spontaneous and unrehearsed, 2) mythological rather than true, and 3) redemptive rather than ambiguous. ${ }^{5}$ There is, of course, nothing forced about real history and memory. Both are mutable, shifting, and even unruly. Neither permits you to prefer your future by filtering your past. In contrast, however, what a considerable number of Europe's citizens are being urged to remember today is all too often designed to help them define the lives they will live to-

Adam Phillips, "The Forgetting Museum," Index on Censorship 2 (2005); available at www.eurozine.com/articles/2005-06-24-phillips-en.html. 
morrow. "The preferred life," in other words, now "has its [own] set of preferred memories."

So, managed memory is not merely a sub-regional problem now. Its deliberate instrumentalization by recent populists is not just a problem within Hungary, the Czech Republic, Slovenia, or Poland, to name a few. It is also an on-going problem confronting "Old Europe" and the institutions it founded. For example, the EU's great contribution to creating a multinational zone of peace is undeniable, but too many of its boosters are transparently silent about the crucial role played by the United States in also establishing this zone. What these particular boosters illustrate is that "history," as a public issue, and as forms of indoctrination and selective memory, continues to frame Europe's political landscape today. ${ }^{7}$ It remains a tool of "instrumental reason," and therefore as an identity-shaping, potentially manipulable device within a Defense Institution Building context.

\section{Socio-Political Realignments}

A dominant popular narrative, if not the dominant one in post-Cold War Western Europe, goes as follows: the West, motivated by deep self-interest and genuine altruism, has dedicated jaw-dropping amounts of time and treasure to bring a benighted "lesser" Europe up to Western standards. This binary "superior-inferior partnership," seldom officially acknowledged, but all too often quietly assumed, has served as the intellectual and emotional backdrop to a myriad number of action plans within NATO and the EU. Its conceptual simplicity has permitted both institutions to control the narrative of European realignment in ways that have suited them best, but the accumulated facts on the ground now point to another equally real narrative.

At present there is a Central, Eastern, and Southeastern Europe beyond "Europe" (i.e., the "Europe" generally promoted by NATO and the EU). On the political level, this alternative Europe is, in Elemér Hankiss's words, a "messy mix" of unity and diversity, centralization and fragmentation, giganticism and localism, enlargement and retrenchment, and much more. ${ }^{8}$ It is a politico-economic space where diverse actors have evolved and continue to transform themselves at different rates and in different ways. As a result, these complex spaces do not resemble the Janus-faced popular narrative that first paired a mature West to a "Wild East" - i.e., a geography populated by backward "others" that have scrambled hard to "catch up." Outside the official narratives of the European Project, there are now multiple and more complex ways to characterize how European realignment, and Eastern European realignment in particular, has evolved, and therefore shaped the identity of Europe in non-binary and non-unilat-

Ibid.

7 See the Eurozine editorial, "European Histories: Towards a Grand Narrative?", Eurozine (3 May 2005); available at www.eurozine.com/articles/2005-05-03-eurozine-en.html.

8 Elemér Hankiss, "Transition or Transitions? The Transformation of Eastern Central Europe 1989-2007" (trans. from original in Hungarian, first published in 2000), Eurozine (26 July 2007); available at www.eurozine.com/articles/2007-07-26-hankiss-en.html. 
eral ways. By way of illustration, Hankiss parses some of these realignment narratives as follows: ${ }^{9}$

- Regime change: Where state socialism has yielded to democracy and open markets

- Incomplete regime change: Where pre-existing power elites continue to operate unhampered behind public institutions that have only partially changed

- A concordance or pact: Where the old elites concluded a power-sharing deal with a new coalition of professionals, economists, entrepreneurs, intellectuals, and managers

- An interrupted revolution: Where the old elites merely converted and consolidated their political power into economic power

- A bourgeois revolution: Where a new upper middle class of "apparatchiks, nouveaux riches, [and] political parvenus" agreed to share power, and now practice unjust forms of nineteenth-century capitalism

- A counterrevolution: Where new power elites dismantled their welfare states and delivered their countries up to the "forces of international economic finance"

- A rise and fall of democracy (otherwise known as "reformed dictatorship" or "stewardship"): Where parliamentary democracy has not truly led to social democracy, where pluralism has degenerated to alternating single-party systems, and where centralized authority, corruption, and ersatz populism retard the growth of civil societies

- Uneven development: Where rapid and disorienting economic and political change has been blunted by "sluggish social renewal," and has therefore thwarted the needed growth of civil societies, including the checks and balances an engaged citizenry so usefully provides

- Continuity: New Europe's recent history may be angular, fractal, and certainly stressful, but it is not by definition unprecedented; it may have fresh features, but only within the continued "intertwining and disentwining" found in long-term historical processes everywhere.

Since the fall of the Berlin Wall, the above realignments have occurred in parts of Europe and the EU, either singly or (more commonly) in different combinations. Old guard political recidivists, aided and abetted by an ever-shifting set of allies, may have re-colonized these spaces to some degree, but the promise and reality of EU membership has also helped prop up still-fragile democratic institutions, perhaps to the point of inviolability. ${ }^{10} \mathrm{EU}$ structures, in form if not in substance, have flourished as a result of the enlargement process, or have extended their benign shadow through the European Neighborhood Policy (ENP). Because of their presence, these structures serve a func-

9 Ibid. 
tion as a partial firewall against local abuses - i.e., as Hankiss notes, they do accelerate social self-organization and eventually lead to functioning civil societies.

So, has Core Europe's influence been a positive one on its once and current periphery? The answer is so obvious that it does not warrant an answer, but we also need to remember that Europe's post-Cold War political space is more complex today than ever. The Janus-faced popular narrative of developed and underdeveloped, senior and junior "partners," or even teachers and pupils may still have some elements of truth to it, but the region-wide realignments that have occurred in the recent past have irrevocably spilled over the walls of this comfortable, one-size-fits-all framework. They overlap, they include new forms, and most importantly they embody a mosaic of transitions and mutual influences in multiple spheres. This, then, is Europe's truest narrative today. Those who quietly continue to believe that "The East is welcome, but should not act above its station" within the European Project miss the essence of this tectonic change, especially when implementing programs at the DIB level. ${ }^{11}$

\section{Possible Near-Term Re-nationalization}

If STRATFOR, a respected private intelligence analysis firm, is correct in its global forecast for 2008, an assertive Russia and a willing Belarus could enter into a formal union together, and thus permit the reintroduction of Russian troops on the Polish border. ${ }^{12}$ If we then link this potentially troubling geopolitical event to others-for example, a predicted massive redistribution of global wealth; the passing of the generational torch to more pragmatically minded European leaders; and the previously mentioned challenges of history and memory and socio-political realignment - there is the shortterm possibility, even with the parallel approval of the Lisbon Treaty, that Europe will slow its march toward political pan-continentalism and tilt back toward a concert of powers arrangement. ${ }^{13}$ Admittedly, for this to happen, other things will have to occur. For example, first of all, France will have to deemphasize its traditional global ambitions, "renovate" its relationship with NATO, and pursue a more Euro-nationalist agenda. Second, Germany will have to continue tilting toward economic and diplomatic nationalism. Third, the U.S. will have to clarify, in substantive terms, its ambivalence toward Europe as a potential "fifth pole" in a multilateral world. Fourth, France and Great Britain will need to reconcile their differing views of ESDP. Finally, workable compromises, however tenuous, will have to appear on the expected roles of the U.S. and Turkey within an EU security framework, and more. ${ }^{14}$ A combination of

11 Perry Anderson, “Depicting Europe," London Review of Books 29:18 (20 September 2007); available at www.lrb.co.uk/v29/n18/ande01_html.

12 See STRATFOR's Annual Forecast for 2008: Beyond the Jihadist War (Austin, TX: STRATFOR, 8 January 2008): 14-17 in particular. Available at web.stratfor.com/images/ writers/STRATFOR_Annual_1_08.pdf.

13 Ibid.

14 Tomas Valasek, "The Roadmap to Better EU-NATO Relations," Centre for European Reform, Briefing Note, December 2007; available at www.cer.org.uk/pdf/briefing_tv_eu_ nato_20dec07.pdf. 
hard-edged geopolitical circumstances and a convergence of forces, as described above, may indeed spur some degree of re-nationalization to occur in parallel with the further institutionalization of the EU. And as is the case with the first two challenges, DIB practitioners need to consider the possible impact of this development on their future efforts.

\section{The Second Requirement: To Look at European Institutions Honestly}

Despite the undeniable transformational impact the EU has had on Europe, especially since its true Year Zero (1989), skeptics are not automatically wrong, nor being churlish, when they claim that the pan-European program remains an amorphous, abstract project. ${ }^{15}$ At this point in time, there is no "whole ecosystem of European discourse," just as there remains a lack of "synchrony" between Old and New Europe. ${ }^{16}$ More specifically, the EU does not have a political or cultural identity "in any meaningful sense of the term," nor does it have a robust mechanism to build civil societies-i.e., "democratic sensibilities"-in other countries. ${ }^{17}$ (EU officials are not tone deaf to these realities. They have declared 2008 to be the Year of Intercultural Dialogue, and have set aside EUR 10 million to "foster a sense of European belonging.")

One reason for the above state of affairs, as Adam Krzeminski observes, is that "the grand old men of European thought still think in 'Old Europe' terms"-i.e., they have not developed a European consciousness that holistically includes, among many other things, the discomfiture with messianic institutions common in the East. ${ }^{18}$ Unfortunately, without this consciousness there cannot be comprehensive socio-political integration either. ${ }^{19}$ Secondly, an incomplete "ecosystem" exists because national interests are still at the heart of Europe's political discourse. (Ironically enough, the re-nationalization process that has recently reemerged on the continent, and the loose political bonds that come with it, first came out of Western Europe.) Finally, because "dialogue" has not always meant dialogue within the official EU narrative-it has actually more often functioned as a semi-encoded demand that others "be like us"-it should come as no surprise that serious weaknesses in the European Project continue to get papered over by its supporters. These weaknesses need to be analyzed bravely, unflinchingly, and honestly, particularly if the problems of history and memory are to be dealt with candidly; if socio-political realignments are to be appreciated for what they are; if re-nationalization, in any guise and to any degree, is to avoid the knee-jerk dis-

15 Peter Rak, "Portrait of a Moment in the Life of a Nation" (originally published in Slovenian in 2006), Eurozine (17 August 2007); available at www.eurozine.com/articles/2007-08-17rak-en.html.

16 Krzeminski, "From Closed Circuits to Communicating Tubes."

17 Martin Sletzinger, "Central and Eastern Europe: Assessing the Democratic Transition," Testimony before the U.S. House of Representatives Foreign Relations Committee, 25 July 2007; available at www.wilsoncenter.org/index.cfm?topic_id=1422\&fuseaction=topics. item\&news_id=269231.

19 Ibid. 
approval of those who want even greater union in Europe; and once again, if Defense Institution Building programs are to be based on the complex reality of actual situations rather than on pre-determined dreams. The following sections will outline some of these weaknesses that must be acknowledged if the European Project is to succeed.

\section{Challenges to the European Project}

\section{An Arguable Self-Image}

Although the EU, as currently structured, is not a fully realized universal-republican model that is suitable for everyone, militant Europeanists believe otherwise. They also see themselves as 1) intrinsically benign actors in international affairs; 2) leading-edge creators of a post-Westphalian political system based on liberal principles and social democratic ideals; 3 ) frontline purveyors of global justice, primarily through the power of example, generous development aid, and the formalizing of international laws and norms; and 4) the providers of "both a political litmus test and a catalyst for national debates and domestic disputes. $" 20$ (The claim in the last case is that the EU can serve as an "honest broker," primarily because of its distance from the "destructive prejudices" and demagoguery so commonly found in national-level politics.) ${ }^{21}$ There is undeniable truth in these self-characterizations, but there is an obvious degree of self-deception as well. In fact, myriad critics have described the EU and its proponents in less flattering terms.

Consider the following, and illustrative, characterization by Perry Anderson. ${ }^{22}$ The EU is nothing more than a caricature of democracy. The European Commission, for example, is a "hybrid executive"-i.e., it is an unelected executive body that also has the power to propose laws. It uses shadowy "coreper" committees to craft legislation with the European Council behind closed doors. The European Parliament, in turn, is a "Merovingian legislature." It remains no more than a "memento of federal hopes foregone." Its limited capacities confirm that what "the core structures of the EU do is convert the open agenda of parliaments into the closed world of chancelleries." In other words, EU structures actually attenuate the politics in politics, and do so with limited accountability. For these reasons and more, where the militant European sees

20 Development, of course, does not automatically promote peace. It may, if it is based on natural resources like oil, gas, or coal, lead to the absence of peace, particularly outside of Europe. See Ott and Sachs, "A New Foreign Policy Agenda"; Anderson, "Depicting Europe"; and Krzeminski, "From Closed Circuits to Communicating Tubes."

21 Anderson, "Depicting Europe." Ivan Krastev provides a more jaundiced view: "[I]n the current epoch, Euro elites secretly dream of a system that will deprive irresponsible voters of the power to undermine rational politics, and ... they are more than ready to use the European Union to realize this dream." The fear appears to be that in the hands of today's masses, voting has stopped being "a choice between policy options" and has become "a revolt against privileged minorities." See Ivan Krastev, "The Populist Moment," Critique \& Humanism 23 (2007); available at www.eurozine.com/articles/2007-09-18-krastev-en.html.

22 Anderson, "Depicting Europe." (The citation applies for the arguments and citations that immediately follow.) 
cause for EU self-satisfaction, Anderson and his fellow travelers see deadly conformism and political vanity, if not outright "illimitable narcissism."

And so the division of opinion continues, not only because the EU's accomplishments are both impressive and disputable, but also because European integration remains an all-consuming secular theology to many - a "theology" that, like its actual predecessors, brooks no rivals. And therein lies the problem. In their zeal to burnish a positive image for a worthy institution, EU boosters have not only sanitized that image over the years, they have also questioned the good taste of those apostates who doubted the EU's principles or methods. Protecting one's self-image, in other words, has become a matter of etiquette and decorum for believers in the Union, who have been known to dismiss what they see as "tactical" concerns or complaints with calls for more "dialogue."

\section{A Commitment to Economic Neo-liberalism}

Despite its own benign self-image ("trust us, we mean well and have your interests at heart"), the EU today constitutes one half of a transatlantic economic empire. ${ }^{23}$ At root, it is an institution that is committed to promoting free markets. It may have a substantive interest in democratization, rule of law, social welfare, and other super-structural elements, but it first and foremost continues to promote and codify neo-liberal economic policies. As a result, deep and lasting social policy today, at least at the European level, may well exist "only in the dreams of disgruntled socialists.",24

It is the financially fluid nation-state, agrees Andrew Moravcsik, which provides the social protections found in Europe today, and therefore permits Brussels not only to pursue policies that stress increased privatization, but also to equate reform with the shrinking of social welfare programs. In this respect, the EU may present a threat to social democratic ideals. ${ }^{25}$ If the Union subscribes institutionally to neo-liberal forms of economics, as Sheri Berman notes, and if the nation-state remains responsible for providing social protections, then the EU's dilution of strong, centralized states, whether intentional or not, actually deprives these states of the policy instruments they need to construct (and preserve) social democratic societies. ${ }^{26}$

\section{An Embracing of Postmodern Forms of Empire}

On the political front, Jan Zielonka admits that the EU today is a "benign empire in action," or an example of "power politics at its best. ${ }^{, 27}$ Robert Cooper, in turn, celebrates

23 Ibid. Reciprocal flows of goods, services, and income receipts from investments totaled USD 1.6 trillion in 2006. See Kristan Archick, "The European Union: Questions and Answers," U.S. Congressional Research Service Report RS21372 (Washington, D.C.: Congressional

Research Service, 23 January 2008), 5.

Ibid.

See Sheri Berman, The Primacy of Politics: Social Democracy and the Making of Europe's Twentieth Century (Cambridge: Cambridge University Press, 2007).

Berman also points out that the assumed link between free markets and democracy has no historical pedigree; it is a post-World War II invention.

Quoted in Anderson, "Depicting Europe." 
the "voluntary imperialism" of today's Europe - a "cooperative empire," based on human rights and bourgeois values, where the strong protect the weak; where the "efficient and well-governed export stability and liberty" to others; and where a "ring of friends" around Europe's perimeter benefit from investment and economic growth. ${ }^{28}$ Herfried Münkler may wring his hands about the obvious messianism behind such a self-image, especially when it comes to promoting human rights, but ultimately he too claims that the EU is no worse than a "sub-imperial" system dedicated to what many believe is a noble dream. ${ }^{29}$

But is it indeed noble? Is the EU selflessly dedicated to promoting a postmodern international order where the blood-drenched political problems of the past become the passionless procedural problems of the present, to be solved by earnest, win-win oriented technocrats in conference rooms throughout greater Europe? Is it "the only global force that has no territorial interests," as Egon Bahr claims, or do those participating in the EU's European Neighborhood Policy know only too well that the quid pro quo for the material prosperity they seek is legal-judicial colonization, no matter how well intentioned and progressive, and the creation of "deep" free trade zones? Are these not "territorial" interests, and are they intrinsically benign? ${ }^{30}$ Do they threaten no one, as Bahr further claims? Or might assorted Afghans, Russians, Serbians, North Africans, those in the Sahel, the Caucasus, or even Central Asia see the EU-this "exemplar of global governance," as Frank-Walter Steinmeir describes it-in less flattering geopolitical terms? ${ }^{31}$ Might some actually see it as being made up of a self-protecting, democracy-distrusting oligarchy that is eager to spread its influence-its "universal" values rather than Western tribal norms - via a dictatorship of good intentions based in Brussels? The potential irony here, of course, is that, "The greater the desire to represent all interests, the weaker the EU becomes." 32

\section{A Lingering Gaullist Interpretation of the Euro-American Relationship}

The consensus among a high percentage of policy elites in Western Europe is that they do share some values with the United States, but that they have also become decidedly more progressive than their American partners, particularly in the areas of law and morality. More particularly, the U.S. seems to keep miring itself in history. Americans attempt to force, rather than inspire, political change in others; they keep colliding with the rules of the road embraced by the "international community" (that ever useful ab-

28 Ibid.

29 Ibid.

30 Egon Bahr, "Europe's Strategic Interests," Internationale Politik-Global Edition 8:2 (Summer 2007): 10-18; available at http://www.ip-global.org/archiv/2007/summer2007/europe--s-strategic-interests.html.

31 Frank-Walter Steinmeier, "Interaction and Integration," Internationale Politik-Global Edition 8:1 (Spring 2007): 50-55; available at www.ip-global.org/archiv/2007/spring2007/ interaction-and-integration.html.

32 Manfred Sapper, Volker Weichsel, and Andrea Huterer, "The Europe Beyond Europe" (first published in German in Osteuropa), Eurozine (21 August 2007); available at www.eurozine.com/articles/2007-08-21-osteuropaed-en.html. 
straction); they see Europe as no more than a pillar of U.S. grand strategy; and they use NATO "as an instrument to marginalize Europe and hamstring the UN.",33 Because of these perceived problems, Europeans cannot and should no longer compromise their values in order to comport with U.S. policy interests, or so the argument goes. ${ }^{34}$ The ethical thing to do is not to be "colonized" by U.S. goals and objectives, but to become a politically autonomous "fifth pole" (along with the U.S., Russia, China, and India) in a multilateral world. Well, is this indeed ethical? Or does ending Europe's "voluntary servitude" to a very convenient "negative federator" also serve the intra- and extra-security ambitions of continental consolidators, many of whom still believe, even if quietly, that NATO and the EU's European Security and Defense Policy (ESDP) represent a zero sum game, and many of whom may not agree that when Europe was less united, it may have been more independent from U.S. foreign policy than of late? ${ }^{35}$

\section{Incomplete Identity Formation (as an EU Project)}

While it was busy expanding to the East, the EU focused on exporting its own rules and procedures, and then ensuring their standardization. Since it did not emphasize "identity formation" with equal vigor, its prospective and eventual members were largely left to their own devices to deal with this profound problem. ${ }^{36}$ (For our purposes, Peter Rak's definition of identity as "a specific referential typicality" is helpful here. ${ }^{37}$ ) The unhappy results have been widespread identity confusion, weltschmerz, clichéd spiritual debates, simulated reform (or, even worse, political vendettas disguised as reform), a tendency toward a public herd mentality, and more. ${ }^{38}$ The results also raise an obvious question: If Central and Eastern Europe remain bureaucratized spaces without cultural and spiritual roots, are "Years of Intercultural Understanding" and last resort shrug-of-the-shoulders responses such as "it will take two generations to sort itself out" helpful or not? Assuming you believe that "no distinctly national culture is now being produced in any of the European nations," just how will things sort themselves out in terms of identity, particularly in the East? ${ }^{39}$

\section{Confusing National Identity with Nationalism}

The widespread hostility of militant Europeanists to anything that smacks of nationalism has few parallels in the world, and not without considerable reason. There is no denying the appalling destructiveness of this force in modern European history. Critics

33 Bahr, "Europe's Strategic Interests."

34 Ibid.

35 Anderson argues this point in "Depicting Europe." He cites cooperation on Afghanistan and a Hamas-controlled Gaza, terrorist renditions (by some), and repeated instances of sub rosa support by France and Germany as proof of his contention.

36 See Imre Kertesz, "Europe's Oppressive Legacy," signandsight.com (19 June 2007); available at www.signandsight.com/features/1382.html.

37 Rak, "Portrait of a Moment in the Life of a Nation."

${ }^{38}$ Ibid. Rak focuses on Slovenia, but his critique reverberates far beyond its borders.

39 James Kurth, "Europe's Identity Problem and the New Islamist War," Orbis 50:3 (Summer 2006): 541-57; available at www.fpri.org/orbis/5003/kurth.europeidentity.pdf. 
such as James Kurth, however, argue that the trans-nationalists have gone too far in their hostility. According to Kurth, they do not blame Europe's bloody history on nationalism per se, but on the national identities that feed it. Needless to say, the two terms (and concepts) are not synonyms for one another, and the sins of the first may have little to do with the present-day realities of the second. Confusing the two, however, does diminish the stature of the nation-state, which we previously pointed out can be a very bad thing indeed, and it only aggravates the problems associated with shaping viable local-regional identities in European populations.

\section{Using the European Neighborhood Policy as a Source of Inclusion and Exclusion}

The EU's ENP is a practical form of self-interested aid. Its goal is to bring "a ring of friends" up to EU standards (in many arenas) without automatically having to offer them the possibility of becoming member states. ${ }^{40}$ The ENP, in other words, is a form of "calculated inclusion" rather than the real thing. In Georg Vobruba's opinion, it permits measured integration without enlargement; it erases "sharp borders"; and it permits the EU to quietly blend internal and foreign policies together at the European community level. ${ }^{41}$ The Union, however, sees its periphery as both a problem and solution, particularly in terms of regional security. That is why the ENP is both inclusionary and exclusionary, but in the latter case it tries to transfer its exclusionary functions to its nearest neighbors. As Vobruba further observes, the latter become convenient buffer states that have to maintain sharp borders, thwart transit networks, participate in deportation chains, and bear other related political-economic costs. Thus the ENP might be a clever way to create a de facto foreign policy, among other things, but one might also ask if its partially exclusionary nature is compatible with the EU's self-image as a beacon of progressive values, and if its concept of burden sharing is fair. (See the next entry.)

\section{Instrumentalizing EU Values}

The EU has few qualms about exporting democratic values (writ large) and good governance in order to establish the preconditions for prosperity and stability on its borders. To use values in this way, however, is to instrumentalize them, and this raises at least three questions:

- Why does the EU see the threats posed by nearby countries differently "if their 'value deficits' are identical or very similar'?

- Why have nations with languishing value deficits nevertheless moved up in the EU membership queue?

40 Georg Vobruba, "Expansion without Enlargement: Europe's Dynamism and the EU's Neighbourhood Policy" (originally published in German in Osteuropa 2-3 (2007)), Eurozine (28 September 2007); available at www.eurozine.com/articles/2007-09-28-vobruba-en.html. 41 Ibid. 
- Why would the EU promote democratic values in a country where forces hostile to those very values might come to power? ${ }^{42}$

The obvious answer to these questions is that geopolitical considerations (first establishing a stable and secure environment, for example) still take precedence over promoting values in and of themselves. In other words, the latter step often times remains a mere means rather than an end. For a values-promoting EU, such realpolitik behavior might be less awkward if the commitment to a constellation of values was less overt.

\section{The Third Requirement: A New Form of European Dialogue}

Despite possible appearances to the contrary, this article is not an exercise in nay-saying. Nor is it a poke-in-the-eye exercise in bad taste - i.e., a deliberate airing of problems best left unexamined, either to facilitate win-win solutions for complex political problems, or to protect the "art of the possible" in European institution building. What I have argued thus far is that the European interregnum has entered a third phase, and that the multivalent narratives used by NATO and the EU since the early 1990s may not be as "reality inclusive" as they once were, either as political explanations or as frameworks for macroscopic change. The system-wide perturbations highlighted in the first section of this article indicate that a more complex European context is emerging, that Europe is certainly no longer a Western enclave centered on mature states. ${ }^{43}$ The other "catch up" states," either within or outside of European structures, are not merely adapting to pre-existing norms and practices, as the dominant "we are integrating" narrative of the EU would have us believe. Instead, they are all combining. ${ }^{44}$ Peripheral Europe, either physically or metaphorically, is just not a partner-pupil anymore. It is, in Gerard Delanty's eloquent words, an inter-civilizational site of re-bordering. It is the site of "cosmopolitan forms of negotiation," and it is therefore creating a "multi-constellation of regions." ${ }^{45}$ In other words, by combining rather than adapting, Europe is creating, again in Delanty's words, a "self-problematizing identity" that is far more fluid and complex than the binary "be like us" world (and basic narrative) of the past.

This development thus brings us to the final question. If Phase Three of the interregnum is about combining rather than adapting, and if it possibly requires DIB practitioners to view the context and challenges of at least one major institution in a more current light (see Part Two), does it also require them to adjust how they cooperate inside and outside of NATO and, even more importantly, the EU? As intimated earlier, when it comes to confederating Europe across multiple pillars, preserving commonality of purpose has historically meant discouraging bureaucratic conflict. The romantic, fist-in-the-air emphasis has always been on being part of a vanguard force - i.e., on

Ibid.

43 Gerard Delanty, "Peripheries and Borders in a Post-Western Europe," Eurozine (29 August 2007); available at www.eurozine.com/articles/2007-08-29-delanty-en.html.

44

Ibid.

45 Ibid. 
working selflessly for a greater good, and on always privileging harmony and solidarity, despite the constant danger of being consumed by a "consensus machine." But again, will this traditional approach help us collectively cope with the "combined" realities discussed earlier? In Markus Miessen's opinion, Europe's preferred form of discourse - friction-preventing consensus - may no longer be up to the task. Instead, current circumstances may demand a "post-consensus" form of dialogue: "productive confrontation." ${ }^{46}$ The latter encourages you to collaborate rather than cooperate; it inspires you to pursue critical distance and engagement rather than ideological conformism; and it reconditions you to not automatically associate institutional conflict with being needlessly provocative and "unhelpful." Productive confrontation, in other words, sees conflict within the European project as a democratic enabler. You continue to interact with (and confront) your partners as you have before, but you do it as an active agent who "recalibrate[s] vectorial forces," and therefore teases unexpected knowledge from the pre-arranged and predictable. "B7 "Better to be a vector than 'doing good'," Miessen argues, and in doing so raises the ultimate consideration for those laboring in the area of Defense Institution Building. ${ }^{48}$ Yes, indeed: new challenges, familiar institutional stress points, and a potentially new form of dialogue - how should we accommodate this narrative, if at all, in the present phase of an ongoing interregnum?

46 See Markus Miessen, "The Violence of Participation: Spatial Practices beyond Models of Consensus," Springerin 1 (2007); available at http://www.eurozine.com/articles/2007-08-01miessen-en.html.

Ibid.

48 Ibid. 
THE QUARTERLY JOURNAL

\section{Bibliography}

Anderson, Perry. "Depicting Europe." London Review of Books 29, no. 18 (2007).

Bahr, Egon. "Europe's Strategic Interests." Internationale Politik-Global Edition 8, no. 2 (2007): 10-18.

Berman, Sheri. The Primacy of Politics: Social Democracy and the Making of Europe's Twentieth Century . Cambridge: Cambridge University Press, 2007.

Delanty, Gerard. "Peripheries and Borders in a Post-Western Europe." Eurozine (2007).

Krastev, Ivan. "The Populist Moment." Critique \& Humanism 23 (2007).

Krzeminski, Adam. From Closed Circuits to Communicating Tubes. 18 June 2007, 2007.

Kurth, James. "Europe's Identity Problem and the New Islamist War." Orbis 50, no. 3 (2006): 541-57.

Miessen, Markus. "The Violence of Participation: Spatial Practices beyond Models of Consensus." Springerin 1 (2007).

Ott, Herrman E., and Wolfgang Sachs. "A New Foreign Policy Agenda." Internationale Politik-Global Edition 8, no. 1 (2007): 16-22.

Phillips, Adam. "The Forgetting Museum." Index on Censorship 2 (2005).

Sapper, Manfred, Volker Weichsel, and Andrea Huterer. "The Europe Beyond Europe." Eurozine (2007).

Steinmeier, Frank-Walter. "Interaction and Integration." Internationale Politik-Global Edition 8, no. 1 (2007). 